Alina Kozarkiewicz

https://orcid.org/0000-0002-0683-3148

Department of Organisational Management, Human Resources Management and Economic Law

Faculty of Management

AGH University of Science and Technology, Kraków, Poland akozarki@zarz.agh.edu.pl

\section{Agnieszka Kabalska}

https://orcid.org/0000-0002-9646-3469

Department of Organisational Management, Human Resources Management and Economic Law Faculty of Management AGH University of Science and Technology, Kraków, Poland akabalska@zarz.agh.edu.pl

\title{
The evolution of business models of Polish health resort enterprises
}

Accepted by Editor Ewa Ziemba | Received: June 8, 2019 | Revised: October 17, 2019 | Accepted: October 22, 2019.

\begin{abstract}
Aim/purpose - The aim of the paper is to explore the evolution of business models of health resort enterprises. The sector is perceived in this research as a case of a particular, traditional sector based on natural (here: balneological) resources which has been undergoing significant changes. In addition to the analysis of the evolution of business models, the purpose was to investigate the role of different categories of resources, e.g. infrastructure or relational competences, in substituting natural resources in the creation of business models.

Design/methodology/approach - The exploration was based on a quantitative approach and survey research. The data gathered through the questionnaire were used in cluster analysis which adopted the agglomeration (hierarchical) method, i.e. grouping of features by Ward's method.

Findings - Business models in the health resort sector in Poland have evolved and the major change incorporated their shift from business models focused on an idiosyncratic category of resources, i.e. natural, balneological resources, to business models based on other categories, like human resources, e.g. employees' competences, tangible resources like modern infrastructure or financial resources (for example contracts). The application of a clustering method facilitated tracing the evolution of business models from various perspectives, such as the importance of interorganiational cooperation, different value propositions, and focus on various customer segments.
\end{abstract}

Cite as: Kozarkiewicz, A., \& Kabalska, A. (2020). The evolution of business models of Polish health resort enterprises. Journal of Economics \& Management, 39(1), 62-82. https://doi. org/10.22367/jem.2020.39.04 
Research implications/limitations - The research implication for management studies is the recognition and presentation of the categories (archetypes) of business models of health resort enterprises in Poland as well as the characteristics of the evolution of business models within the scope of their components. The primary practical implication from a managerial perspective is to provide the basis for evaluation of opportunities and threats related to the adopted business model when comparing to the alternatives currently chosen by competitors. The major limitation of the research is the small sample size.

Originality/value/contribution - The paper presents the results of the original research conducted among health resort enterprises in Poland. The paper identifies and characterises various categories (archetypes) of business models of the health resort enterprises in Poland as well as the evolution of the building blocks of implemented business models. The study contributes to the discussion on the usefulness of resource-based-view (RBV) as a theoretical perspective of business model research. The results are consistent with $\mathrm{RBV}$ as well as adhere to competence approach and relational view. From a practical perspective, they offer a recipe (formula) for managers of health resort enterprises interested in introducing changes into their business models.

Keywords: business model, business model evolution, health resort.

JEL Classification: I11, M20.

\section{Introduction}

For over 50 years now, the term 'business model' has been present in scientific discussions (Wirtz, Pistoia, Ullrich, \& Göttel, 2016), giving rise to research on a variety of issues (Grzywa, 2015). A considerable number of works have been published on the business model concept (e.g. Hedman \& Kalling, 2003; Massa, Tucci, \& Afuah, 2017; Osterwalder, Pigneur, \& Tucci, 2005; Wirtz, Göttel, \& Daiser, 2016). The majority of the studies referred to business model components (e.g. McGrath, 2010; Shafer, Smith, \& Linder, 2005), classification of business models (e.g. Dubosson-Torbay, Osterwalder, \& Pigneur, 2001; Lambert, 2015; Timmers, 1998) and business model innovation (e.g. Amit \& Zott, 2010; Casadesus-Masanell \& Zhu, 2012; Chesbrough, 2010). Although a multitude of issues was discussed, there are even-present research topics to be explored. One of the most auspicious research questions suggests the evolution of business models presumed as a dynamic phenomenon, i.e. the change of business models over time. The transformation could be explored on the level of an entire sector or industry - music industry (Vaccaro \& Cohn, 2004), sustainable technologies (Bohnsack, Pinkse, \& Kolk, 2014), airline sector (Bieger \& Agosti, 2005) or regenerative medicine (Banda, Tait, \& Mittra, 2018) as examples. An alternative research perspective is to study the evolution of a business model of a specific organisation or enterprise. Such a perspective was used for instance by 
Demil \& Lecocq (2010) to investigate the business model change of Arsenal FC, or by Sosna, Trevinyo-Rodríguez, \& Velamuri (2010) when Naturhouse business model was explored. The third possibility is to focus on specific components of business models, such as value proposition, customer segments or cost innovation (Willamson, 2010).

In this paper, we aim to investigate the evolution of business models and their components in a very traditional sector based on natural (i.e. balneological) resources. The exploration allowed us to uncover a variety of business model categories along with paths of their evolution.

Our research focuses on the sector of Polish health resort enterprises. This sector has undergone significant changes in recent years - from very traditional and state-supported enterprises based on exploitation and usage of natural resources towards modern, innovative and market-oriented businesses attracting younger customers and foreign tourists. The additional aim of the research is to discover the role of other, non-balneological resources or competences in the creation of business models.

As the main aim of our research is to analyse the evolution of business models in a specific sector, we have decided to take into consideration the dynamic approach (Grzywa, 2015) and the activity system perspective (Zott \& Amit, 2010). In our view, a business model is a bundle of resources and interrelated activities with an emphasis on value creation (Zott \& Amit, 2010). Accepting such an approach to business model definition, we conducted our study according to resource-based view (e.g. Barney, 1991), regarding resources as the main source of superior performance in the chosen sector - as was referred, natural resources are the critical type of resources laying foundation for the development of health resorts in Poland. Moreover, we strived to tie our study to the role of intangible resources, thus we link the research with competence approach (Sanchez \& Heene, 1997) and relational view (Dyer \& Singh, 1998). The hypothesis we put for consideration assumes that the growing importance of interorganisational cooperation and the development of new categories of competences have resulted in the evolution of business models of health resort enterprises - from 'traditional' models, based on balneological resources, to more 'modern' business models, based on competences or a wide market offer.

We seek to stress that, apart from the study of archetypes of business models, our research refers to the additional methodological issue, i.e. the possibility of using quantitative methods, cluster analysis in particular, to discover and describe the paths of the evolution of business models. 
The paper has been organised in the following way. The literature review is focused particularly on the topic related to the evolution of business models researched so far. The third section is concerned with the methodology used for this study. The fourth, empirical section presents the findings of the research, focusing on business models' archetypes and evolution of business model building blocks. The discussion summarised the research results. The conclusions are drawn in the final section, where new exploration topics for further research on business models and their evolution are suggested.

\section{Theoretical considerations and prior literature review}

Much progress has recently been made in developing the business model concept. The growing interest in the business model could be seen in both management research and business practice. It might be related to changing conditions of how contemporary enterprises operate, including the utilisation of the Internet and modern information technologies (Zalega, 2018), new rules for acquiring resources (e.g. outsourcing) and development of interorganisational cooperation within networks (Wiechoczek, 2016).

There is a considerable variety of business model definitions. The business model is understood as architecture, design, pattern, plan, assumption, and statement (Morris, Schindehutte, \& Allen, 2005). A business model is the organisation's core logic for creating value (Linder \& Cantrell, 2000), a method of doing business (Rappa, 2001), a story that explains how the enterprise works (Magretta, 2002), the logic of the firm, the way it operates and how it creates value for its stakeholders (Casadesus-Masanell \& Ricart, 2010), a system of resources and interdependent activities that transcends the focal firm and spans its boundaries (Amit \& Zott, 2010), or a description of how an organisation creates, delivers, and captures value (Osterwalder \& Pigneur, 2010). The prevalence of the business model concept became a challenge for authors - not only in defining the business model, but also in retracing the evolution of business models in particular.

The inspection of prior literature offers interesting insight into systematic literature reviews (e.g. Wirtz, Pistoia, Ullrich, \& Göttel, 2016) as well as into typologies of approaches taken into consideration in research so far (e.g. Grzywa, 2015). The summary of theories applied by authors as the foundations for the research into business models confirms both the variety of theories as well as their compatibility with the main research perspective (Grzywa, 2015). An interesting question on how strategic management theories are connected 
with business model research (Ritter \& Lettl, 2018) reveals that business model research offers a necessary and valuable 'connecting point' for several theories business models contribute to the academic discussion by enabling a connection between theories. In this study, RBV creates the foundations for the discussions, however, this well-known view is complemented by competence approach (Sanchez \& Heene, 1997) focused on the role of organisational competences, and relational view (Dyer \& Singh, 1998) focused on relations and networks, and their significance in achieving competitive position and superior performance. This issue seems to be extremely important in the sector based on traditional, tangible, natural resources which is approaching the necessity of introducing changes to meet new expectations of customers and new market conditions.

This area - the planned and emerging change and evolution of business models - seems to be of particular interest in recent research. The evolution of business models drew the attention of numerous researchers, thus offering a wide possibility of scientific discussions, from contingencies and contexts to archetypes and their performance. The so-called transformational approach (dynamic view) is essential in the research on business model evolution, allowing one to study the modifications - their direction and scope.

There are numerous interesting studies into the evolution of business models ${ }^{1}$. According to the Gorevaya \& Khayrullina (2015), one of the leading trends is the change and transformation of business models by virtue of the technological impact, i.e. IT convergence technologies (offline IT) and virtual space (online). The authors suggested that the accelerating potential of IT and new management tools had a significant impact on developing business model networks, where a number of business functions are available for sharing.

Demil \& Lecocq (2010) put under consideration how a business model evolves with a particular focus on the dynamics created by the interactions between its building blocks. The authors have chosen Arsenal F.C. as their case study. It is assumed that the business model should be described with three core components such as resources and competences, organisational structure and propositions for value delivery. They presumed that evolution is represented by sequences that comprise intertwined, determined and emergent changes, affecting core components or their

\footnotetext{
In the following paper, we conducted systematic literature review (SLR) on the evolution of business models. The first stage of SLR incorporated title and abstract search in peer-reviewed journals via Business Source Complete and Academic Search Complete databases of EBSCO (we have searched the phrase 'business model evolution' in both title and abstract of the paper). The analysis of the results allowed us to single out four papers that unambiguously concern the business model evolution as well as evolution of business models within the scope of BM components.
} 
elements. These sequences implied that the business model is permanently in a state of transitional imbalance, where some parts could be retrieved by decisions made by management, but some could not be restored in the short term.

Bohnsack, Pinkse, \& Kolk (2014), based on the example of electric vehicles and sustainable technology, identified four business model archetypes as well as traced their evolution over time. They distinguished the following business model archetypes: luxury specific-purpose, luxury multi-purpose, economy specificpurpose, and economy multi-purpose vehicles. The framework for the evolution of business models included three pivotal components: value proposition, value network, and revenue/cost model. The analysis demonstrated that firms did not make radical changes to the value proposition, and the majority of adjustments occurred in the value network and the revenue/cost model.

The paper presented by Majava \& Isoherranen (2019) explored the evolution of customer care business models in the smartphone industry. Additionally, the authors were able to study how after-sales service business models have changed from the traditional customer care business model for physical products (Nokia) to a physical-service combination (iPhone from Apple), and further to a pure software and service model (Google Android). Moreover, Majava \& Isoherranen (2019) complemented their conclusions by a presentation of the directions of the evolution of all nine elements that construct Osterwalder \& Pigneur's Business Model Canvas (BMC): value proposition, customer segments, channels, customer relationships, revenue streams, key resources, key activities, key partners and structure of costs (Osterwalder \& Pigneur, 2010) ${ }^{2}$.

The research presented in this paper is based on similar assumptions - the investigation is focused on tracing the modifications in business models and the major components of BMC. Considering the breadth of transformations that took place in the sector of Polish health resort enterprises, the paper offers a promising area for studying changes in business models. So far, there has been an insufficient discussion about the diversification of business models of health resort enter-

2 Business Model Canvas (BMC) is a one of the tools that allows designing, describing and modifying a business model. A business model could be described through nine building blocks that represent the intended logic of earning money (Osterwalder \& Pigneur, 2010). Customer Segments identify groups of people or organisations that an enterprise intends to reach and serve. Value Proposition includes the description of products and services that benefit a specific Customer Segment. Channels determine how the company communicates its value proposition to the customer. Customer Relationships specify the types of interrelations established between the company and customers; Revenue Streams reflect the cash generated from Relationships. Key Resources represent crucial assets of a company and Key Activities define actions required for preparing and delivering the offer. Key Partnerships are the representation of crucial partners, while Cost Structure describes costs related to operations in the business model. 
prises, and the categorisation of business models archetypes in this sector, which in the authors' belief, creates interesting research potential. This indicates a requirement for the study that would provide new insight into the changes of business models in the long-established sector, traditionally based on natural resources, but at present, operating in a new, more competitive environment. Additionally, this research offers the possibility of testing the application of hierarchical cluster analysis as a quantitative tool for discovering the archetypes of the business model.

\section{Research methodology}

The research is based on a quantitative approach. The study was conducted in the form of a survey at the turn of October and November of 2017. The initial sample consisted of 135 health resort enterprises from Poland ${ }^{3}$. The questionnaires were addressed exclusively to health resort enterprises, which both were located in one of 45 resort towns in Poland, and offered sanatorium treatment. Conclusively, 48 (36\%) enterprises participated in the study.

The questionnaire had two sections - the first part featured closed-ended questions, referring to the characteristics of health resort enterprises. The questions pertained to crucial components of BMC (Osterwalder \& Pigneur, 2010). The second, more comprehensive questionnaire segment, included questions that referred to factors and conditions reflecting the particular features of health resort enterprises. The questions were classified into five main categories, likewise, reflecting the key components of BMC, i.e. value proposition, customers, key resources, key processes, and key partners.

The collected data were used in cluster analysis. For this research, Statistica 13.1 Multidimensional Analysis module was employed. Features, that is data from the first part of the questionnaire, were agglomerated by using Ward's method, and the Euclidean distance was used as a distance measure. Cluster analysis was chosen for categorising business models, due to the advantages resulting from its use

\footnotetext{
3 The investigation into health resort enterprises in Poland was reasoned by the significant changes and challenges taking place in this sector (i.e. demographic changes, new healthy lifestyle trends, as well as growing competition and legal changes). The subjects' selection was deliberate and included two major stages. In the first stage, we selected resorts with treatment contracts, signed with Polish financing entity, e.g. National Health Fund (NFZ), Social Insurance Institution (ZUS) or State Fund for Rehabilitation of Disabled Persons (PFRON). The second stage involved verification of the prepared database - for further considerations, we have only chosen these facilities (both private and state-owned) which were listed in the Register of Health Care Entities. Health resort hospitals as well as medical spa hotels were excluded from the study (they represent different business models: non-commercial and strictly commercial, respectively, while the business models of health resort enterprises combine both approaches simultaneously).
} 
in scientific research. The primary purpose of grouping methods is to detect clusters from empirical data. In a cluster analysis, objects are grouped with the principle of maximising similarity within a layer and minimising class similarity. Cluster analysis could be applied to the creation of taxonomy, i.e. the organisation of observations in the hierarchy of classes that group similar objects. Cluster analysis is one of the most common exploratory methods that allows assembling (as knowing the number of objects) the ones that are as close as possible to the rest (Rand, 1971). One of the most widespread agglomeration methods, i.e. when two clusters are similar enough to be combined, is the Ward's method, while the Euclidean distance is the most common, standard distance measure for continuous data (Gan \& Tao, 2017). In conclusion, the agglomeration allowed not only distinguishing the categories of business models and their individual types but also tracing the evolution of business models in the analysed sector.

\section{Research findings}

\subsection{Business model archetypes}

The results of the feature agglomeration are presented on the dendrogram (Figure 1). The dendrogram analysis allowed us to distinguish two general categories of business models, thus, the classification was based on the criterion of acquiring natural resources.

Figure 1. Dendrogram presenting the results of cluster analysis (grouping of features)

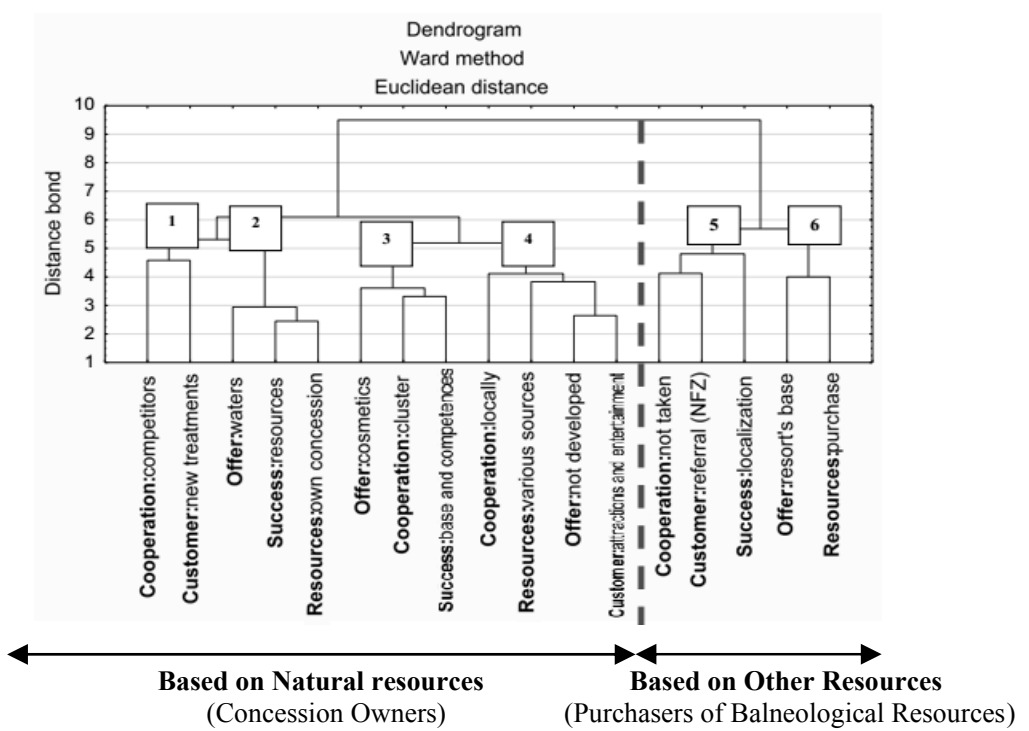

Source: Authors' evaluation. 
The first category was referred to as Concession Owners and represented companies that hold geological concession for the exploitation of balneological resources, i.e. mineral and therapeutic waters, medicinal mud, and therapeutic gases. The second group, Purchasers of Balneological Resources, featured health resort companies that buy natural curative resources from other entities, either use various sources, both internal and external. The line separating two major groups of business models is marked on the diagram as a dashed line. Business models of health resort enterprises were identified and distinguished in terms of their differentiation in the value proposition, serving different customer segments and different customer relationships, diversity of key activities, and key partnerships.

Within the category of business models Based on Natural Resources/ Concession Owners, two main subcategories were differentiated. The Balneological Resources represented models built primarily on balneological resources and provision of services based on these resources. The Market Player group embodied business models of enterprises concentrating on natural curative resources, targeting commercial sanatorium offer and operations likewise. Four business models were grouped under subcategories discussed above; the authors gave them names, which, in their opinion, reflected the most important features of the models: Treatment and Spring in Balneological Resources subcategory, and Competency and Partner in Market Player subcategory (Figure 2). Companies with the Treatment business model provide a first-rate sanatorium treatment offer to their customers. The term 'spring' in the traditional sense means a curative town where sources of healing waters could be found. In this paper the Spring business model embraced companies with a relatively limited offer and activities primarily based on mineral or therapeutic waters. The Competency model was based on distinctive competences held by health resort enterprises and expressed through the development of a sanatorium base and skills enabling the preparation of a sanatorium offer and balneological cosmetics. Enterprises with the Partner model did not develop their offer, but interacted with other entities - first and foremost, this model was based on cooperation. The business model numbers in Figure 1 correspond to the numbering and names of business models summarised in Figure 2. 
Figure 2. Categories of business models of health resort enterprises in Poland based on grouping of features

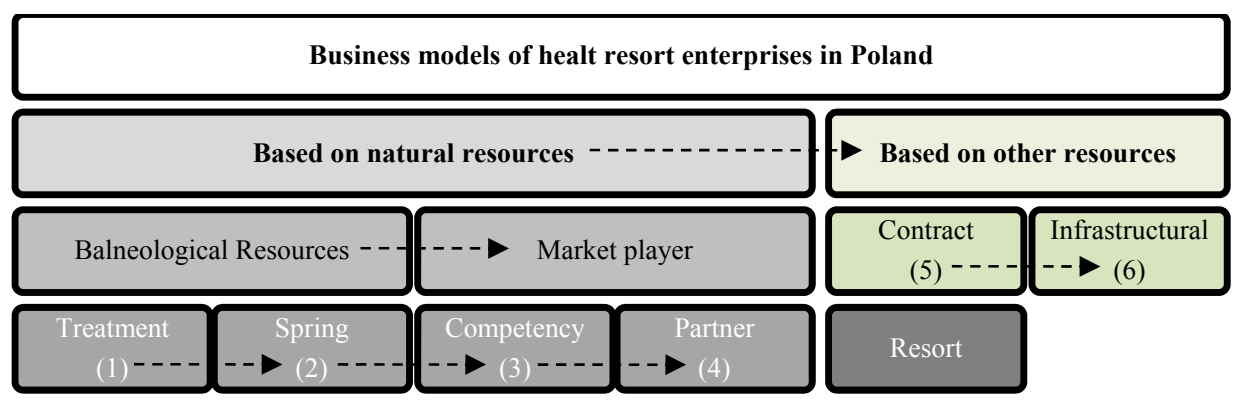

Source: Authors' evaluation.

From the diagram above it could be noticed that in the case of BM based on non-geological resources, the Contract model with the Resort variant and the Infrastructural business model have been identified. The essence of the Contract model is the orientation on customers 'financed' throughout contracts with the Polish National Health Provider (NFZ). The Resort business model employed an attractive geographical location that brings the attention of both sanatorium customers and tourists. In the Infrastructural business model, enterprises recognised their potential in the development of sanatorium and spa infrastructure.

Arrows in Figure 2 demonstrated the directions of the evolution of business models. The evolution was initiated with Concession Owners' business models, focused particularly on balneological resources, towards models that were based on non-balneological resources in Purchasers of Balneological Resources.

\subsection{Evolution in business model building blocks}

It is important to remark that cluster analysis allowed for the exploration of evolution in business model building blocks. Figure 3 presents the rearrangements in acquiring balneological resources, simultaneously reflecting changes in the perception of the relevance of natural resources in sanatorium operations. The conversion began with their major significance, meant by relying the business model and the offer on balneological resources in the Spring model, through the utilisation of resources from various sources in the Partner model, up to relying only on external sources. 
Figure 3. Illustration of changes in obtaining key resources in business models
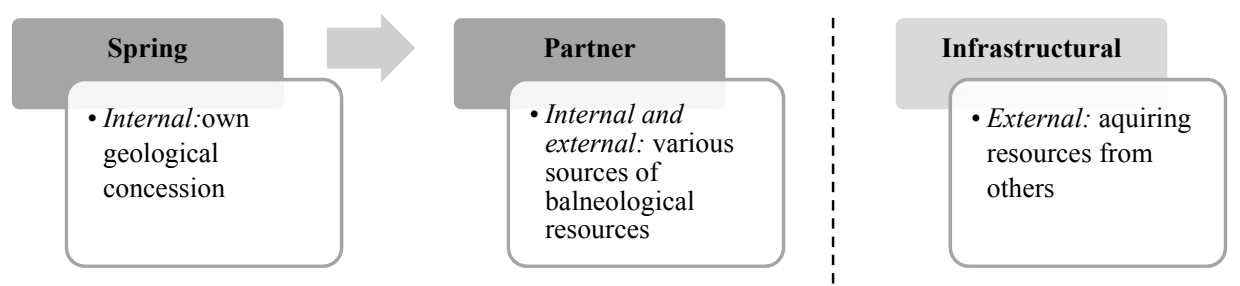

Source: Authors' evaluation.

The Infrastructural business model benefits from balneological resources provided by other entities, indicating the decreasing significance of natural resources in the companies' offer. In the Spring model, balneological resources are unquestionably important due to their use in the production of bottled mineral waters. The Partner business model is a collaborative one - based on cooperation with local entities, e.g. local authorities, cultural institutions, schools and usage of both own and external resources from partners. The Infrastructural business model is defined by a focus on material resources, mainly, the development of the spa and recreational base, like swimming pools, as the core of the offer of the company development, and therefore, the basis of the value proposition.

The evolution in the value proposition (Figure 4) incorporated the following perspectives: from the value created, above all, on the basis of natural resources in Spring model, through value based on the utilisation of both tangible and intangible resources, e.g. sanatorium base and competences in the Competency model.

Figure 4. Examples of the evolution of value proposition in business models
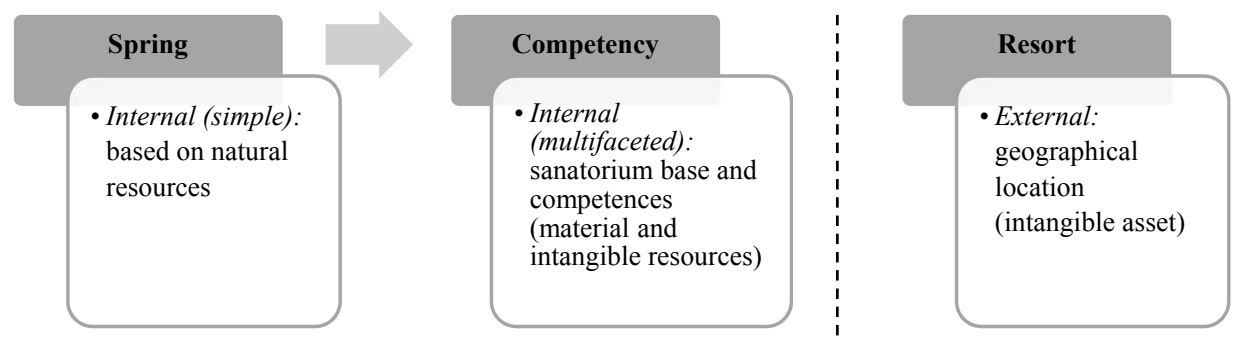

Source: Authors' evaluation.

Moreover, value is based on intangible resources, e.g. an attractive geographical location in the Resort model. The usage of balneological resources in the Spring business model discussed above, and thus their key importance for the competitive advantage, could be compared to the multifaceted internal 
sources of competitive advantage in the Competency model. This business model relied mainly on the development of competences, with reference to the value proposition, e.g. developing sanatorium base and skills. Material resources, like sanatorium and spa base, as well as personnel competences and skills, are the keys to the competitive advantage. In the Resort business model, an attractive geographical location is a keystone for value proposition - it is an 'external' source that has not been developed by the enterprise itself.

As presented in Figure 5, the evolution reflected an imperceptible stinting of activities in models Based on Natural Resources - starting from the offer of supplementary products, e.g. bottled waters in Spring or natural cosmetics in Competency model, leading to the 'optimal' offer where modifications are not applied and no additional activities are performed (Partner model).

Figure 5. Illustration of changes in key activities undertaken by health resort enterprises
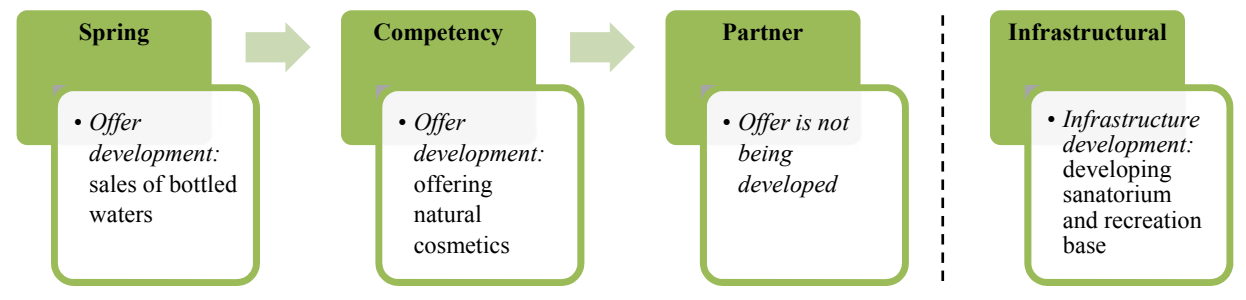

Source: Authors' evaluation.

Within the subcategory of Balneological Resources, one could notice an interesting phenomenon, namely, undertaking more advanced and complex activities, associated with the production of cosmetics and other natural-based products, i.e. processing balneological resources in the Competency model. In the Infrastructural model, where balneological resources are obtained from the 'outside', the development of material resources could be observed via operations by extending the offer to have an up-to-date spa and sanatorium infrastructure, the company attracts new customers, like tourists.

Customer segments and customer relationships were the subjects of evolution as well, as shown in Figure 6. Within the group of Concession Owners, enterprises tend to shift from internal to mixed approaches to endear them to their customers - leaning toward attractions and entertainment rather than sanatorium treatments alone. 
Figure 6. Evolution of acquiring customer segments in business models

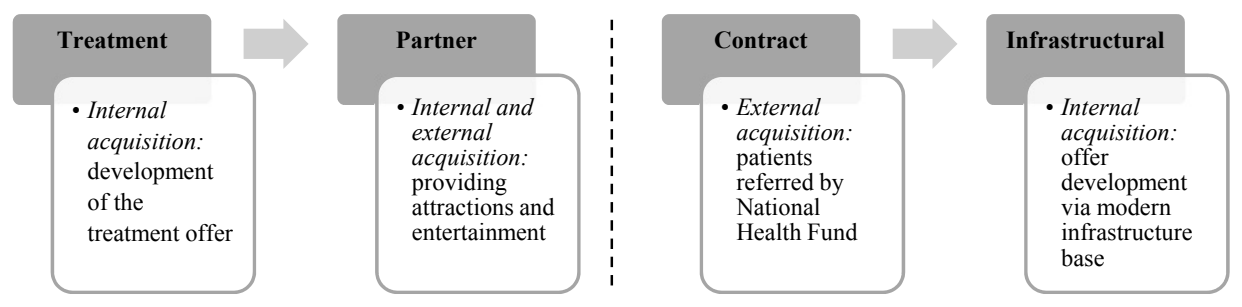

Source: Authors' evaluation.

Enterprises with Concession Owners business models are aspiring to attract customers via their resources and competences. For instance, a well-developed treatment offer included new sanatorium treatments in the Treatment model. Customers are interested in improving their own health and well-being; therefore, a diverse offer of therapeutic and rehabilitation treatments is the most appropriate approach to gain their interest. In the Partner model, the treatment offer is not modified, however, the enhanced cooperation and utilisation of other categories of resources resulted in providing an additional offer, featuring various attractions and entertainment.

In business models based on non-balneological resources, a reversed reorientation process could be observed - from acquiring customers via contracts with NFZ and providing specified treatment to sanatorium patients in the Contract model, to own offer development, based on infrastructure in Infrastructural model. The key customer segments in Contract business models are patients, participating in treatment and rehabilitation programmes under contracts, whereas, in the Infrastructural model, the majority of customers are interested in a commercial, curative and/or recreational offer.

Figure 7 is an illustration of a plurality of resources in the category of business models based on non-balneological resources. The evolution went from models relying on indentures in the Contract model, models based on attractive geographical location like Resort model, through a model which is built around modern infrastructure base and its development as in the Infrastructural model.

Ultimately, interorganisational cooperation is heterodox in different business models. However, one could notice that in models in the Concession Owners category, various forms of cooperation are undertaken (Figure 8). Its extent is heterogeneous - from the macro scale in the Treatment model (partnerships with competitors from all over Poland), through midi scale cooperation in a cluster in Competency model - development of relational competences allowed for 
cooperation with various entities gathered in a specific, geographical location, as far as micro-scale, where cooperation involves local entities, such as local government, schools or cultural centres, is included as in Partner model.

Figure 7. Multifariousness of resources in business models based on non-balneological resources

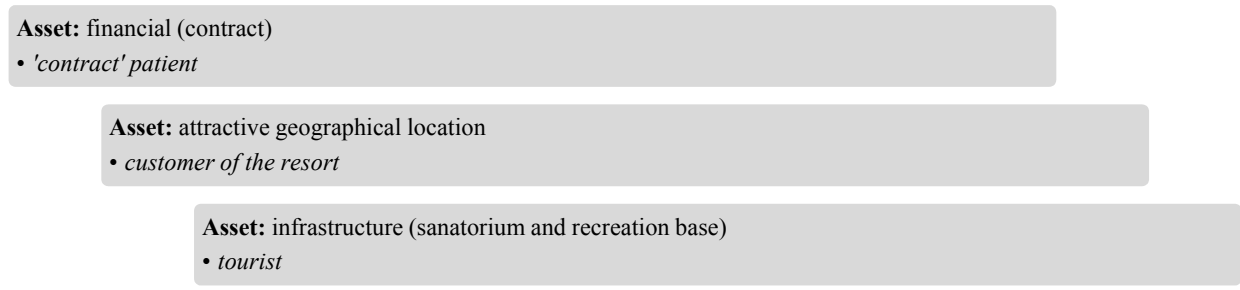

Source: Authors' evaluation.

Figure 8. Diversity and evolution of interorganisational cooperation
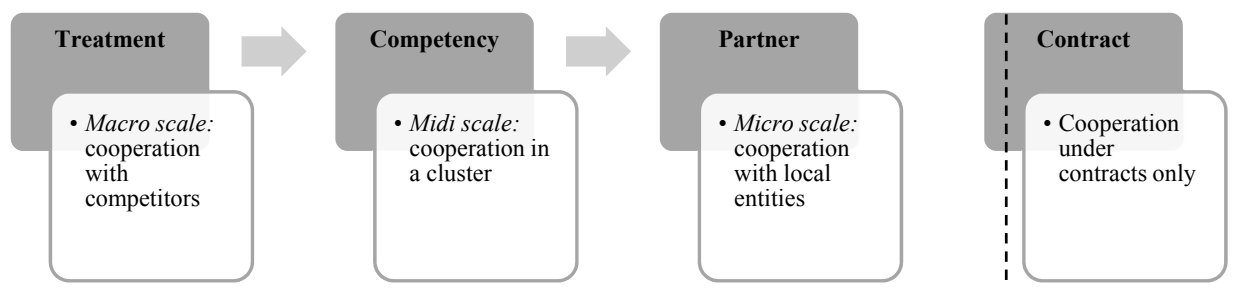

Source: Authors' evaluation.

The Contract model is an exceptional one; the cooperation is based primarily on contracts with the National Health Provider. The funding obtained from the contracts has a fundamental impact on the remaining components of this business model - value proposition or customer segments in particular.

\section{Discussion}

The presented study on business models - their categories, diversity, and evolution, contributes to the current research on one of the traditional sectors in Poland, i.e. the sector of health resort enterprises. In this regard, the original research findings brought substantial relevance to the existing knowledge - categorisation of business models made it possible to achieve the research goal, i.e. to follow the evolution of business models, both in the general scope (How business models have changed?) and detailed (How did the building blocks of the business models change?). 
The investigation into the evolution of business models revealed an alteration in the creation of value proposition - from focusing on natural resources to non-balneological resources, such as material resources (e.g. sanatorium infrastructure), competences and employees' experience. The study has found that there is a significant change within the activities that are undertaken by health resort companies. Taking into account growing customers' expectations and strong competition in the sector, it is assumed that health resort enterprises would extend their value chains by adding value to various customers. As to answer the research question, health resort enterprises are currently implementing 'new' business models; more and more often, business models are based on intangible resources and competences. What is more, the cluster analysis made it possible to discover and describe the paths of the evolution of business models, as discussed in the examples of business model components ${ }^{4}$.

The consistent relevance of 'contract' customers and contracts with the NFZ constitute an important category of customers, specific for the Contract business model. When analysing the paths of the evolution of business models, it was stated that some health resort companies strived to serve a specific customer segment, e.g. contract customers mentioned above. In terms of interorganisational cooperation, the results of clustering of features have demonstrated that narrowing cooperation could be observed, however, health resort enterprises are still interacting with various entities. Due to the growing importance of cooperation in the sector (Januszewska, 2005; Mirek, 2014), it should be assumed that business models of health resort enterprises would evolve towards models based on partnership and complementarity of resources and activities.

The central hypothesis of this paper stated that the growing importance of interorganisational cooperation and the development of new categories of competences, primarily relational ones, have resulted in the evolution of business models of health resort enterprises as well as the quest for new sources of competitive advantage. The findings of the study demonstrated that business models of health resort enterprises in Poland evolved from 'traditional' models, based on natural or material resources (e.g. Treatment or Spring), into 'modern' business models based on competences or a complex offer (e.g. Competency and Partner).

${ }^{4}$ Clustering of business models in identifying BM categories was successfully administered by Camisón \& Villar-López (2010) in creating taxonomies of business models in Spanish industry, Claudio-González, Martín-Baranera, \& Villarroya (2016) in their research on business models of Spanish journals or Farne \& Vouldis (2017) while identifying business models of the banks in the euro area. The utilisation of clustering methods in constructing business model taxonomies was also discussed by Groth \& Nielsen (2015). 
The advancement of new technologies, infrastructure or networks has a significant impact on the sector's development. These findings fully met the theoretical assumptions - they confirm the role of non-natural assets in the evolution of business models. The scope of changes in business models concerns possibilities of obtaining balneological resources due to cooperation (long-term relations), extending the value chain by offering additional products or services as well as progressing specialization in serving a specific customer segment due to particular competences, or broadening the cooperation with local partners or even competitors. The results of this research are consistent with RBV, and particularly with the competence approach (Sanchez \& Heene, 1997) and relational view (Dyer \& Singh, 1998). The research confirms the role of resource-based-view as a valuable lens in explaining the changes in business models of organisations oriented towards a better market position.

\section{Conclusions}

A considerable amount of literature has been published on business models, however, an undiminished interest in this concept and the multitude of research topics were a solid base for the conclusion that the concept of a business model still is an important and inspiring research topic. Researchers devoted great interest to the problem of defining the concept, simultaneously attempting to categorize business models or analyse the possibilities of their modifications and innovations. However, the evolution of business models in specific sectors continually remained to be an interesting research topic.

Little is known about business models of Polish health resort enterprises, and there has been no or little discussion about business model evolution in this sector. For that reason, the paper was a response to a research gap in this area. Apart from theoretical consideration, it offers some practical implications. From the manager's perspective, research results could be the basis for assessing the opportunities and threats resulting from the adopted business model compared to other alternative approaches, currently selected by competitors, provide managers with opportunities to name their business model or to observe some characteristics of business model archetypes, discussed in this paper.

The results of the cluster analysis unveiled various paths of evolution of business models of health resort enterprises in Poland. The findings revealed the growing tendency to build business models on non-balneological resources. The results of the empirical research and observation of trends within the sector allowed for the conclusion that business models are evolving towards proinnovative and pro-customer ones. 
The major research limitation resulted from the small research sample. Apart from discussing the role of sample size in future investigations, the authors suggest some new directions for future research. In-depth research into interorganisational cooperation, its further evolution and the development of relational competences seem to offer an interesting area for exploration. Based on the current analysis, it is concluded that cooperation in the health resort sector could as well be analysed in the context of, among others, the ability to serve new customer segments, examine the evolving role of foreign clients in creating value proposition, as well as customisation of sanatorium and spa services towards value co-creation by recipients of sanatorium services.

\section{References}

Amit, R. H., \& Zott, Ch. (2010). Business model innovation: Creating value in times of change. IESE Business School Working Paper, 870, 1-17. https://doi.org/10.2139 /ssrn.1701660

Banda, G., Tait, J., \& Mittra, J. (2018). Evolution of business models in regenerative medicine: Effects of a disruptive innovation on the innovation ecosystem. Clinical Therapeutics, 40(7), 1084-1094. https://doi.org/10.1016/j.clinthera.2018.06.003

Barney, J. (1991). Firm resources and sustained competitive advantage. Journal of Management, 17(1), 99-120. https://doi.org/10.1177/014920639101700108

Bieger, T., \& Agosti, S. (2005). Business models in the airline sector - evolution and perspectives. In W. Delfmann, H. Baum, S. Auerbach, \& S. Albers (Eds.), Strategic management in the aviation industry (Chapter II, pp. 41-65). Aldershot: Ashgate Publishing Group. https://doi.org/10.4324/9781315242316-3

Bohnsack, R., Pinkse, J., \& Kolk, A. (2014). Business models for sustainable technologies: Exploring business model evolution in the case of electric vehicles. Research Policy, 43(2), 284-300. https://doi.org/10.1016/j.respol.2013.10.014

Camisón, C., \& Villar-López, A. (2010). Business models in Spanish industry: A taxonomy-based efficacy analysis. M@n@gement, 13(4), 298-317. https://doi.org/10. 3917/mana.134.0298

Casadesus-Masanell, R., \& Ricart, J. E. (2010). From strategy to business models and onto tactics. Long Range Planning, 43(2-3), 195-215. https://doi.org/10.1016/ j.lrp.2010.01.004

Casadesus-Masanell, R., \& Zhu, F. (2012). Business model innovation and competitive imitation: The case of sponsor-based business models. Strategic Management Journal, 34(4), 464-482. https://doi.org/10.1002/smj.2022

Chesbrough, H. (2010). Business model innovation: Opportunities and barriers. Long Range Planning, 43(2-3), 354-363. https://doi.org/10.1016/j.lrp.2009.07.010 
Claudio-González, M., Martín-Baranera, M., \& Villarroya, A. (2016). A cluster analysis of the business models of Spanish journals. Learned Publishing, 29, 239-248. https://doi.org/10.1002/leap.1046

Demil, B., \& Lecocq, X. (2010). Business model evolution: In search of dynamic consistency. Long Range Planning, 43, 227-246. https://doi.org/10.1016/j.lrp.2010. 02.004

Dubosson-Torbay, M., Osterwalder, A., \& Pigneur, Y. (2001). E-business model design, classification and measurements. Thunderbird International Business Review, 44, 5-23. https://doi.org/10.1002/tie.1036

Dyer, J., \& Singh, H. (1998). The relational view: Cooperative strategy and sources of interorganizational competitive advantage. The Academy of Management Review, 23(4), 660-679. https://doi.org/10.2307/259056

Farne, M., \& Vouldis, A. (2017). Business models of the banks in the euro area. European Central Bank Working Paper, 2070, 1-46. https://doi.org/10.2866/386225

Gan, J., \& Tao, Y. (2017). On the hardness and approximation of Euclidean DBSCAN. ACM Transactions on Database Systems, 42(3), 1-45. https://doi.org/10.1145 13083897

Gorevaya, E., \& Khayrullina, M. (2015). Evolution of business models: Past and present trends. Procedia Economics and Finance, 27, 344-350. https://doi.org/10.1016/ S2212-5671(15)01005-9

Groth, P., \& Nielsen, C. (2015). Constructing a business model taxonomy: Using statistical tools to generate a valid and reliable business model taxonomy. Journal of Business Models, 3(1), 4-21. https://doi.org/10.5278/ojs.jbm.v3i1.1211

Grzywa, E. K. (2015). Modele biznesu w naukach o zarządzaniu - główne nurty badawcze [Business models in management science - main research perspectives]. Przeglad Organizacji, 3, 20-27. Retrieved from https://przegladorganizacji.pl /artykul/2015/10.33141po.2015.03.03

Hedman, J., \& Kalling, T. (2003). The business model concept: Theoretical underpinnings and empirical illustrations. European Journal of Information Systems, 12(1), 49-59. https://doi.org/10.1057/palgrave.ejis.3000446

Januszewska, M. (2005). Perspektywy rozwoju uzdrowisk w Polsce [Perspectives for the development of spa resort in Poland]. Turystyka i rekreacja, I, 116-120. Retrieved from https://www.awf.edu.pl/_data/assets/pdf_file/0014/20543/Januszewska_M_ Perspektywy_rozwoju_uzdrowisk_w_Polsce.pdf

Lambert, S. C. (2015). The importance of classification to business model research. Journal of Business Models, 3(1), 49-61. https://doi.org/10.5278/ojs.jbm.v3i1.1045

Linder, J., \& Cantrell, S. (2000). Changing business models: Surveying the landscape. (Working Paper, pp. 1-15). Dublin: Accenture Institute for Strategic Change. Retrieved from http://www.businessmodels.eu/images/banners/Articles/Linder_Cantrell.pdf

Magretta, J. (2002). Why business models matter. Harvard Business Review, 80(5), 86-92. Retrieved from https://hbr.org/2002/05/why-business-models-matter 
Majava, J., \& Isoherranen, V. (2019). Business model evolution of customer care services. Journal of Industrial Engineering and Management, 12(1), 1-12. https://doi. org/10.3926/jiem. 2725

Massa, L., Tucci, Ch. L., \& Afuah, A. (2017). A critical assessment of business model research. Academy of Management Annals, 11(1), 73-104. https://doi.org/10.5465 /annals.2014.0072

McGrath, R. G. (2010). Business models: A discovery-driven approach. Long Range Planning, 43, 247-261. https://doi.org/10.1016/j.lrp.2009.07.005

Mirek, J. (2014). Innowacyjność jako czynnik funkcjonowania i rozwoju polskich uzdrowisk [Innovativeness as a factor of Polish resorts functioning and development]. Handel Wewnętrzny, 6(353), 251-265. Retrieved from http://cejsh.icm.edu.pl/cejsh /element/bwmeta1.element.desklight-553c1dd5-fd60-4779-a460-dbbfb11f87d7

Morris, M., Schindehutte, M., \& Allen, J. (2005). The entrepreneur's business model: Toward a unified perspective. Journal of Business Research, 58, 726-735. https:// doi.org/10.1016/j.jbusres.2003.11.001

Osterwalder, A., \& Pigneur, Y. (2010). Business model generation: A handbook for visionaries, game changers, and challengers. Hoboken: John Wiley \& Sons.

Osterwalder, A., Pigneur, Y., \& Tucci, Ch. L. (2005). Clarifying business models: Origins, present, and future of the concept. Communications of the Association for Information Systems, 16, 1-25. https://doi.org/10.17705/1CAIS.01601

Rand, W. (1971). Objective criteria for the evaluation of clustering methods. Journal of the American Statistical Association, 66(336), 846-850. https://doi.org/10.2307/ 2284239

Rappa, M. (2001). Managing the digital enterprise - business models on the web. North Raleigh, NC: Carolina State University. Retrieved from http://digitalenterprise.org /models/models.html

Ritter, T., \& Lettl, C. (2018). The wider implications of business-model research. Long Range Planning, 51(1), 1-8. https://doi.org/10.1016/j.lrp.2017.07.005

Sanchez, R., \& Heene, A. (1997). Reinventing strategic management: New theory and practice for competence-based competition. European Management Journal, 15(3), 303-317. https://doi.org/10.1016/S0263-2373(97)00010-8

Shafer, S. M., Smith, H. J., \& Linder, J. C. (2005). The power of business models. Business Horizons, 48, 199-207. https://doi.org/10.1016/j.bushor.2004.10.014

Sosna, M., Trevinyo-Rodríguez, R. N., \& Velamuri, S. R. (2010, April-June). Business model innovation through trial-and-error learning: The Naturhouse case. Long Range Planning, 43(2-3), 383-407. https://doi.org/10.1016/j.lrp.2010.02.003

Timmers, P. (1998). Business models for electronic markets. Journal of Electronic Markets, 8, 3-8. https://doi.org/10.1080/10196789800000016

Vaccaro, V. L., \& Cohn, D. Y. (2004). The evolution of business models and marketing strategies in the music industry. International Journal on Media Management, 6(1-2), 46-58. https://doi.org/10.1080/14241277.2004.9669381 
Wiechoczek, J. (2016). Creating value for customers in business networks of high-tech goods manufacturers. Journal of Economics and Management, 23(1), 76-90. Retrieved from http://cejsh.icm.edu.pl/cejsh/element/bwmeta1.element.cejsh-0fc30602 -d5af-4912-a218-59283aeafd47

Willamson, P. J. (2010, April-June). Cost innovation: Preparing for a 'value-for-money' revolution. Long Range Planning, 43(2-3), 343-353. https://doi.org/10.1016/j.lrp. 2009.07.008

Wirtz, B. W., Göttel, V., \& Daiser, P. (2016). Business model innovation: Development, concept and future research directions. Journal of Business Models. 4(1), 1-28. https://doi.org/10.5278/ojs.jbm.v4i1.1621

Wirtz, B. W., Pistoia, A., Ullrich, S., \& Göttel, V. (2016). Business models: Origin, development and future research perspectives. Long Range Planning, 49(1), 36-54. https://doi.org/10.1016/j.lrp.2015.04.001

Zalega, T. (2018). Collaborative consumption in consumer behavior of Polish young people. Journal of Economics and Management, 33(3), 136-163. https://doi.org/ 10.22367/jem.2018.33.08

Zott, C., \& Amit, R. (2010). Business model design: An activity system perspective. Long Range Planning, 43(2-3), 216-226. https://doi.org/10.1016/j.lrp.2009.07.004 